\title{
LIBERDADE DE EXPRESSÃO E RELAÇÕES CONTRATUAIS TRABALHISTAS: RUPTURA DISCIPLINAR DO PACTO LABORAL DECORRENTE DAS IDEIAS, CRÍTICAS E REFLEXÕES EXPRESSAS PELO EMPREGADO NAS REDES SOCIAIS
}

Paulla Christianne da Costa Newton

Doutorado com menção "Doutorado Europeu" em Direito do Trabalho e Previdência Social pela Universidade de Valencia - Espanha, com instância de investigação na Universidade Clássica de Lisboa, em Portugal; Mestrado em Direito Econômico pela Universidade Federal da Paraíba (UFPB); Master em Direito do Trabalho e Previdência Social pela Universidade de Valencia - Espanha; Professora de Direito do Trabalho do Curso de Direito do Centro Universitário de João Pessoa (UNIPÊ) e professora titular de Direito do trabalho do Centro de Ciências Jurídicas da Universidade Estadual da Paraíba (UEPB).E-mail: paulla.newton@ gmail.com

Sérgio Cabral dos Reis

Doutorando em Direito pela Universidade Federal de Santa Catarina (UFSC). Mestre em Direito Processual e Cidadania pela Universidade Paranaense (UNIPAR). Máster em Teoria Crítica en Derechos Humanos y Globalización pela Universidad Pablo de Olavide (Sevilla, Espanha). Professor efetivo da Universidade Estadual da Paraíba (UEPB). Professor da graduação e da pós-graduação do Centro Universitário de João Pessoa (UNIPÊ). Professor da Escola Superior da Magistratura Trabalhista da Paraíba (ESMAT XIII). Professor convidado da Escola da Magistratura Trabalhista de Pernambuco (ESMATRA VI). Professor convidado da Escola Superior da Advocacia da Paraíba (ESA-PB). Ex-juiz do trabalho no Paraná e em Sergipe. Juiz do Trabalho na Paraíba. E-mail: sergio.juiz@gmail.com

\section{Resumo}

A presente investigação aprecia o exercício do direito fundamental à liberdade de expressão e os potenciais conflitos nas relaçôes contratuais trabalhistas decorrentes do uso das tecnologias da informação e da comunicação pelo empregado. Desta forma, examinam-se os preceitos essenciais que norteiam à liberdade de expressão e os valores limítrofes para o legítimo exercício deste direito fundamental. Nesta seara, os interrogantes cruciais que norteiam a temática em comento centram-se nos efeitos jurídicos oriundos das di- 
retrizes fundamentais da liberdade de expressão consoante as manifestaçóes de ideias, reflexões e críticas efetuadas pelo trabalhador, mediante a utilização das redes sociais e a aplicação da máxima penalidade disciplinar pelo empregador, com a consequente ruptura do pacto laboral. Logo, a tríade composta pelo direito fundamental à liberdade de expressão, as expressóes manifestadas pelo empregado nas esferas virtuais e a dispensa disciplinar por falta grave do trabalhador protagonizam o debate adiante exposto.

\section{Palavras-chave}

Liberdade de expressão; Redes sociais; Dispensa disciplinar.

\section{Resumen}

La presente investigación tiene como obyecto principal diseñar lineamientos sobre el ejercicio del derecho fundamental a la libertad de expresión y los probables conflictos derivados del uso de las tecnologías de la información y de la comunicación por el empleado en las relaciones laborales. Así, se lleva a cabo el análisis de los preceptos esenciales que comprenden la libertad de expresión y los límites reconocidos para el ejercicio efectivo de este derecho fundamental. Con efecto, el estudio examina los efectos jurídicos derivados de las directrices fundamentales de la libertad de expresión en relación con las manifestaciones de ideas, reflexiones y críticas vertidas en las redes sociales por el empleado, considerándose la aplicación de la máxima penalidad disciplinaria por el poder patronal, con la ruptura del pacto laboral. Siendo así, las discusiones presentadas en la presente investigación tienen como protagonistas el derecho fundamental a la libertad de expresión, las manifestaciones expresas por el empleado en las redes sociales y el despido disciplinario del trabajador.

\section{Palabras clave}

Libertad de expresión; Redes sociales; Despido disciplinario.

\section{Introdução}

A sociedade contemporânea pós-moderna ou pós-industrial é uma sociedade complexa, pluralista e fragmentada, marcada pela revolução da técnica, pela mundialização da economia e pela massificação dos meios de comunicação.

Conforme preleciona AMARAL (2003), "pós-modernidade" é um conceito extremamente vago e ambíguo, utilizado, frequentemente, para rotular a sociedade contemporânea, ao exprimir ideias diversas que têm, como denominador comum, uma postura crítica e de desconstrução da modernidade estética e científica da primeira metade do século passado. 
Em decorrência da pós-modernidade, estão em crise os modelos ideológicos de compreensão da realidade da época industrial. Transformam-se as circunstâncias da realidade e os modelos para a sua compreensão. A pós-modernidade caracteriza-se como uma era de incertezas e instabilidades, constatando-se a impossibilidade de dominação das consequências da tecnologia em suas mais amplas dimensões espaço-temporais (MORAES, 2010).

A violência, por força das incertezas decorrentes do avanço tecnológico, ampliou o seu potencial na pós-modernidade. Em outros termos, a lógica da competição exacerbada, o deslumbramento diante da novidade tecnológica e a ausência de valores éticos ou marcos regulatórios que definam limites e rumos, podem ameaçar a sobrevivência da própria humanidade.

É grande o volume de informaçóes, mas, também de maneira paradoxal, a sociedade está condenada à superficialidade, inclusive pelo fato de que a estética vem em substituição à ética e a aparência torna-se mais importante que o conteúdo (SARMENTO, 2008).

Neste cenário emblemático e obscuro, em constante ebulição, constroem-se e aperfeiçoam-se novos paradigmas assecuratórios dos patamares mínimos para a coexistência humana. No conjunto de preceitos e direitos fundamentais de tutela aos cidadáos, a liberdade de expressão firma-se como pedra angular para o pleno desenvolvimento do caráter democrático e participativo dos indivíduos, no cerne dos Estados Democráticos de Direito.

A presente investigação tem como objeto geral o exame da relação entre o uso das redes sociais e a aplicação da máxima penalidade disciplinar pelo empregador, com a ruptura do pacto laboral por ilícito obreiro, considerando-se a perspectiva dos ditames de tutela do direito à liberdade de expressão.

Para tanto, utilizamos os métodos de procedimento analítico-descritivo e o comparativo. Sendo assim, dissecamos um conjunto de documentos internacionais, normativas e construçóes doutrinárias que abordam às temáticas propostas para o objeto investigado, priorizando uma abordagem crítica e reflexiva. Ademais, procedemos a uma análise jurisprudencial comparativa, com decisóes derivadas dos tribunais brasileiros, espanhóis e dos Estados Unidos. A escolha pelos sistemas citados, explica-se pelos seguintes fatores: o Brasil é o país onde, amiúde, desenvolvemos nossas atividades profissionais e pesquisas acadêmicas; a Espanha é o país sede para o evento de internacionalização do CONPEDI, especificamente, em Madrid, nesse ano de 2015, e, os Estados Unidos por apresentarem uma decisão de considerável relevância para a questão da liberdade de expressão com relação às redes sociais.

Para o encadeamento lógico das ideias adiante expostas, propomos a bifurcação da análise em dois momentos. Preliminarmente, a especificaçáo dos preceitos atinentes aos 
fundamentos essenciais que norteiam o direito à liberdade de expressão e, em um segundo momento, o exame das dissonâncias pertinentes à relação do uso das redes sociais, dispensa por sanção disciplinar do trabalhador e os preceitos assecuratórios da liberdade de expressão.

Em seguida, procedemos aos argumentos finais e a apresentação dos instrumentos referenciais.

\section{Direito Fundamental à Liberdade de Expressão}

\subsection{Fundamentos Objetivo e Subjetivo da Liberdade de Expressão}

A liberdade de expressão constitui uma conquista fundamental para o constitucionalismo liberal. Sendo assim, o reconhecimento de tal direito representa um espaço de segurança para o cidadáo em face ao Estado. Neste patamar, diversos documentos internacionais de tutela aos Direitos Humanos trataram, explicitamente, da construção de paradigmas essenciais para o respeito à liberdade de expressão no cerne da sociedade internacional.

Assim, entre os textos internacionais, destacamos o conteúdo exposto pelos regramentos mais relevantes, responsáveis por inspirarem os dispositivos constitucionais de um grande número de países. Com efeito, a Declaração Universal de Direitos Humanos (1948), em seu artigo 19, explicita que "todo indivíduo tem direito à liberdade de opinião e expressão". O Pacto Internacional de Direitos Civis e Políticos (1966) determina que "Ninguém poderá ser molestado devido as suas opiniōes" (art.19, 1). Em âmbito americano, o art. $4^{\circ}$ da Declaraçáo Americana dos Direitos e Deveres do Homem (1948) afirma que "Toda pessoa tem direito à liberdade de investigação, de opinião e de expressão e difusão do pensamento por qualquer meio". Em idêntico sentido, o art.13 da Convenção Americana sobre Direitos Humanos (1969) preconiza que toda pessoa tem direito à liberdade de pensamento e de expressão. Na seara Europeia, a Convenção Europeia para a proteção dos Direitos Humanos e as Liberdades Fundamentais (1950) posiciona-se em similar sentido, ao determinar que toda pessoa tem direito à liberdade de expressão, direito que compreende a liberdade de opinião e a liberdade de receber ou de comunicar informaçóes ou ideias sem a interferência das autoridades públicas (art.10).

Conforme o expresso no contexto dos regramentos internacionais, podemos inferir que o Direito Fundamental à liberdade de expressão compreende a manifestação de pensamentos, ideias e emissóes de opinióes pessoais e crenças por parte de um determinado sujeito ou uma coletividade, sem a interferência abusiva dos poderes estatais.

MARTÍNEZ (2002) diferencia o conteúdo objetivo e subjetivo da liberdade de expressão. Dessa forma, sob a perspectiva objetiva, pode-se afirmar que os direitos 
fundamentais encontram-se aparelhados por uma gama de diretrizes objetivas e garantias institucionais que originam diversas obrigaçóes para os Poderes constitucionalmente investidos. Considera-se que, neste cenário, esta liberdade torna-se imprescindível para o exercício de outros direitos fundamentais, como também, para a plena consecução dos alicerces de toda sociedade democrática.

Visto deste modo, desdobram-se três consequências de essencial relevância para o nosso estudo: primeiro, enquanto direito fundamental, a liberdade de expressão irradia seus efeitos, como princípio objetivo, em todos os âmbitos do direito; segundo, sobeja a obrigação objetiva com relação aos poderes públicos de promoverem, fomentarem e conservarem o bem jurídico tutelado pelo direito fundamental em apreço; e, terceiro, o dever objetivo dos poderes públicos de consolidarem normas materiais e procedimentais para a efetiva consecução do direito fundamental à liberdade de expressão (MARTÍNEZ, 2002).

Logo, percebe-se uma amplitude efetiva com relação ao exercício e a consecução de paradigmas que norteiam o direito à liberdade de expressão em sua perspectiva objetiva. Assim, constituem titulares do direito à liberdade de expressão, todos os cidadãos, sem gravames discriminatórios. Em contrapartida, como princípio irradiante no cerne dos ordenamentos jurídicos, obriga tanto os poderes estatais constitucionalmente investidos, como também os particulares, no âmago das relações privadas constituídas.

Em seu conteúdo, o direito à liberdade de expressão desenha-se como direito subjetivo que consiste na manifestação exterior de expressões da consciência ou abstenção em fazê-lo, de forma livre e voluntária, sem a oposição, obstáculos ou interferências impostas pela potestade estatal.

A Doutrina Constitucional espanhola entende que a liberdade de expressão concretiza-se com a expressão subjetiva da pessoa, seja pensamento, ideia, crença, juízo de valor ou opinião, mediante a difusão através de meios naturais, como gestos e palavras ou mecanismos técnicos de reprodução (ESPANHA. Sentença do Tribunal Constitucional. Madrid. Competência Tribunal Pleno. Sentença 12/1982. Recurso de Amparo 227/1981. Publicação 31/03/1982).

Em território nacional, o Supremo Tribunal Federal deverá julgar, nos próximos dias, uma das questóes mais emblemáticas sobre liberdade de expressão, já discutidas por aquela Corte. Trata-se do caso do jornalista sergipano José Cristian Góes que foi condenado civil e criminalmente pela publicação de uma crônica de ficção em seu blog, em maio de 2012. A crônica trazia referências à corrupção, ao nepotismo e ao coronelismo, sem a citação de nomes ou datas (HERVIEU, 2013). Acontece que, por ocasião da crônica apresentada pelo jornalista, o Desembargador do Tribunal de Justiça do Estado de Sergipe Edson Ulisses sentiu-se ofendido por algumas expressóes utilizadas pelo autor em seu texto, tendo decidido processar o jornalista, civil e criminalmente. Processos que resultaram 
favoráveis ao Desembargador, nas instâncias preliminares, sobejando, a decisão final pela Corte Suprema.

Ao considerar-se uma nítida afronta aos pilares da liberdade de expressão, o caso vem repercutindo vorazmente no cenário internacional, resultando em uma Reunião na Comissão Interamericana de Direitos Humanos da Organização dos Estados Americanos e na confecção de um dossiê entregue à Relatoria de Liberdade de Expressão da Organização das Naçốes Unidas.

Neste patamar, não se pode obscurecer que as manifestaçóes antagônicas, críticas, devem ser consideradas como legítimas, porquanto inerentes à pluralidade de expressões, pilar fundamental à construção das sociedades democráticas.

\subsection{Diretrizes e Balizas ao Exercício Legítimo do Direito à Liberdade de Ex- pressão}

Enquanto direito fundamental, deve-se enfatizar que o direito à liberdade de expressão também possui paradigmas limítrofes para o seu exercício, relativizando-se quando em confronto com outros bens jurídicos de tutela fundamental ao pacífico convívio nas sociedades. Com efeito, há que se considerar como inviável a absoluta prevalência do direito à liberdade de expressão em detrimento de outros valores, de substancial relevância à vivência social. Por certo, o homem que não vive sob o domínio das normas não passa de uma besta selvagem (BAUMAN, 2014). E, para nos afastarmos deste estado bestial, as concessóes recíprocas são necessárias, em prol do equilíbrio entre as garantias e os direitos constitucionalmente consagrados.

Neste contexto, a Declaração Universal de Direitos Humanos (1948) assevera que para o exercício dos direitos e liberdades, as pessoas submetem-se às limitaçóes legalmente estabelecidas com a finalidade de assegurar o reconhecimento e o respeito em relação aos direitos dos demais sujeitos e para a satisfação da moral, da ordem pública e do bem estar geral (art.29, 2). Por sua vez, a Convenção Americana sobre Direitos Humanos (1968), em seu inciso 2, do artigo 13 preconiza que o exercício do direito à liberdade de pensamento e expressão pode sujeitar-se a existência de responsabilidades ulteriores, as quais devem encontrar-se expressamente fixadas pela lei, sendo necessárias para garantir o respeito aos direitos ou à reputação dos demais sujeitos ou a proteção à segurança nacional, a ordem pública ou a saúde ou a moral públicas. Igualmente, a Convenção Europeia para a Proteção dos Direitos Humanos e das Liberdades Fundamentais (1950) determina que o exercício da liberdade de expressão poderá submeter-se a determinadas formalidades, condições, restriçóes ou sanções, legalmente previstas, que constituam medidas imprescindíveis para a segurança nacional, a integridade territorial ou segurança pública, a defesa da ordem e a prevenção de delitos, a proteção da saúde e da moral, a proteção da 
reputação e dos direitos alheios, entre outros valores necessários à preservação da sociedade democrática (art.10, 2).

Portanto, a liberdade de expressão encontra balizas tanto no cerne das relaçóes entre os particulares e a atuação dos poderes estatais, como nas relaçóes de cunho estritamente privado. Assim as coisas, preliminarmente, concebem-se como limites os confrontos e conflitos entre o direito à liberdade de expressão e a presença de outro direito fundamental, os preceitos éticos e morais, e a ordem pública e a paz social.

De esta forma, cabe ponderar-se os valores tutelados com relação aos outros direitos fundamentais existentes, como os direitos da personalidade, considerando-se, nesta hipótese, a análise do caso em concreto e as circunstâncias que norteiam a situação.

Nesta seara, cabe considerar os ditames pertinentes ao princípio da proporcionalidade. Com efeito, seja como decorrência do Estado Democrático de Direito (concepção alemã), seja como decorrência do devido processo legal (concepção norte-americana), ou ainda como derivação do princípio da isonomia, é certo que a proporcionalidade é uma técnica fundamental de solução das inevitáveis colisóes entre direitos fundamentais (TAVARES, 2007).

"A proporcionalidade é um valor, em virtude de que se caracteriza como metanorma, estando acima das normas jurídicas" (GÓES, 2004, p.71). Em outros termos, princípio autônomo (PEREIRA, 2006) ou mero postulado normativo aplicativo (ÁVILA, 2010), a proporcionalidade vincula a produção legislativa e a solução judicial de litígios à observância dos direitos fundamentais. Trata-se, enfim, de instrumento de interpretaçáo jurídica e conteúdo da norma fundamental do Direito, já que "serve para analisar a relação entre interesses e bens que estejam em confronto" (PEREIRA, 2006, p.319).

Independentemente da concepção adotada, são elementos da proporcionalidade a "conformidade" ou "adequação" dos meios empregados, a "necessidade" ou "exigibilidade" da medida adotada e a "proporcionalidade em sentido estrito". Esses dois primeiros elementos correspondem aos pressupostos fáticos do princípio, enquanto que o último equivale à ponderação jurídica destes (TAVARES, 2007, p. 685).

A adequação dos meios a serem utilizados diz respeito à correlação entre meio e fim, da razoabilidade do meio selecionado ao objetivo. Pela idoneidade ou adequação, em outros termos, exige-se que toda restrição aos direitos fundamentais seja idônea para o atendimento de um fim constitucionalmente legítimo (PEREIRA, 2006). Conforme esclarece ÁVILA, "um meio é adequado quando promove minimamente um fim" (ÁVILA, 2010, p.185).

A exigibilidade equivale à melhor escolha, dentre os meios adequados, para atingir a finalidade. Nas palavras de ÁVILA, "um meio é necessário quando não houver meios 
alternativos que possam promover igualmente o fim sem restringir na mesma intensidade os direitos fundamentais afetados" (ÁVILA, 2010, p.185).

Enquanto na necessidade do meio empregado para realizar a finalidade jurídica a ser concretizada no caso, busca-se otimizar as possibilidades "fáticas", procura-se, na proporcionalidade em sentido estrito, otimizar as possibilidades "jurídicas”, com balanceamento ou ponderação entre os valores previstos na ordem jurídica quanto às desvantagens do meio em relação às vantagens do fim perseguido (TAVARES, 2007), mas sem ferir o conteúdo essencial de um direito fundamental ou viabilizar um intolerável desrespeito à dignidade humana (GUERRA FILHO, 2003). No particular, ÁVILA é enfático: “O meio será desproporcional se a importância do fim não justificar a intensidade da restrição dos direitos fundamentais" (ÁVILA, 2010, p.185).

No âmago das relaçóes laborais, deve-se recordar que a existência do pacto laboral entre empregado e empregador pressupóe um conjunto recíproco de direitos e obrigaçóes, capitaneado pelo dever de lealdade e boa fé. De forma que, manifestaçóes da liberdade de expressão que podem ser legítimas em outras situaçóes, poderão representar quebra dos deveres contratuais quando manifestadas no contexto do vínculo laboral (MARTÍNEZ, 2002).

De esta forma, ante o pacto laboral, não se pode admitir a adoção pelo sujeito contratado de comportamentos, práticas e expressóes deliberadamente nocivas ao contratante, em explícita violação aos deveres contratuais de natureza não patrimonial, como a lealdade, a boa fé e a confiança.

Sem embargo, cabe salientar que o trabalhador não estará privado, de forma absoluta, do seu direito fundamental de liberdade de expressão. Isto seria absurdo para os preceitos singulares da cidadania, pluralidade e democracia. O que se busca preservar é, precipuamente, a conservação de uma relação contratual pautada nas diretrizes da boa fé e da lealdade e, por outro lado, a exteriorização legítima e ordenada das ideias e opinióes do trabalhador, com base no exercício constitucionalmente assegurado do seu direito à liberdade de expressão.

Direito fundamental e relação contratual privada devem coexistir harmonicamente, de forma a conferir-se uma perfeita adequação das basilares diretrizes contratuais à livre manifestação das ideias, opiniōes e reflexóes do trabalhador. Neste aspecto, em particular, a tarefa torna-se árdua, posto que há uma linha tênue, com ampla carga de subjetividade, entre as manifestaçóes explícitas do preceito fundamental de liberdade de expressão e a observância estrita das diretrizes da boa fé contratual, conforme as reflexóes ofertadas no tópico seguinte.

\section{Dissonâncias Oriundas da Ruptura do Contrato de Trabalho por Infração Obreira Decorrentes do Uso das Redes Sociais pelo Trabalhador. Aspec- tos Propedêuticos}

A ruptura do contrato de trabalho constitui a máxima sanção aplicada ao trabalhador, conforme prerrogativa inerente ao poder disciplinar do empregador contratante. 
Nestes termos, a prática de uma infração grave pelo empregado viabiliza a desconstituição justificada do pacto laboral pelo empregador, por impossibilidade absoluta de continuidade do vínculo empregatício. Hipótese em que o empregador exime-se do pagamento das parcelas indenizatórias.

Vale enfatizar que no ordenamento jurídico brasileiro, a gravidade do ilícito praticado pelo trabalhador para justificar a dispensa disciplinar, pressupóe a existência de uma tipificação expressa pelo legislador trabalhista. Condutas descritas no rol do artigo $482 \mathrm{da}$ Consolidação das leis trabalhistas (BRASIL, 1943).

Sob a ótica da aplicação da penalidade disciplinar, cabe ressaltar que o uso das redes sociais pelo trabalhador encontra-se adstrita a hipóteses diferenciadas, conforme o modo, o objetivo e o meio no qual o trabalhador utiliza os meios informáticos. Nesta seara, cabe diferenciarmos três situaçóes corriqueiras geradas pelo uso das redes sociais e suas conseqüências para as relaçóes de trabalho: o uso das redes durante a jornada laboral; o uso das redes sociais em meio privado, mas com vinculação expressa ao exercício das atividades laborais e os comentários e expressóes ideológicas nas redes sociais.

\subsection{Uso das Redes Sociais Durante a Jornada Laboral}

Com relação ao uso das redes sociais no curso da realização das atividades, cabe verificar a legitimidade na utilização das mesmas pelo trabalhador, de maneira a não trazer efeitos nocivos ou potenciais danos à organização da estrutura empresarial.

Nesse particular, torna-se inadmissível que o empregado utilize-se das redes sociais de forma que coloque em risco à segurança das informaçóes empresariais, atente contra as normas impostas pelo empregador para coordenar o uso dos meios informáticos ou prejudique o seu rendimento e a sua produtividade.

Resulta óbvio que, o acesso abusivo das redes sociais pelo trabalhador durante o horário destinado ao exercício das atividades laborais conduz ao rompimento do pacto laboral por grave quebra da boa fé contratual, viabilizando a aplicação da sanção máxima pelo empregador.

Igualmente configurar-se-á como abusivo o uso se a empresa proíbe, expressamente, a utilização dos computadores para atos alheios à atividade laboral, mediante a adequação de regras para o acesso dos recursos informáticos. Sem embargo, há uma tendência na jurisprudência social espanhola em não reconhecer-se a procedência do despido disciplinar do trabalhador, mesmo quando ele se utilize dos meios informáticos para situaçóes particulares durante a jornada laboral, quando a empresa não o tenha informado, categoricamente, sobre as restriçôes para o uso destas ferramentas no ambiente laboral (GRANDE; GORDILLO, 2013). 
Por certo, torna-se pressuposto para a configuração da infração obreira a tipificação ante a legislação trabalhista; sendo assim, cabe ao empregador nortear a conduta dos seus contratantes subordinados através da fixação de diretrizes comportamentais para o uso das tecnologias de informação e comunicação, deixando explícito a gravidade da conduta aos que desrespeitarem às ordens legitimamente impostas.

Por sua vez, a Alta Corte trabalhista brasileira desconstituiu uma ruptura do contrato de trabalho por ilícito do trabalhador que desrespeitou norma interna de conduta, imposta pela empresa para regulamentar o uso dos meios informáticos. Com efeito, em 2008, uma indústria metalúrgica de São Paulo demitiu um empregado por infração obreira, pelo fato de ter o obreiro acessado o Orkut durante o expediente, deixando armazenado no computador da empresa um registro fotográfico do seu órgão genital. O empregador alegou descumprimento de norma interna que vedava o acesso a sites de relacionamento. No entanto, o Judiciário trabalhista desconstituiu a sanção disciplinar, tendo entendido que a sanção foi aplicada de maneira excessiva, não sendo o fato grave o suficiente para ensejar a ruptura contratual, mesmo encontrando-se o trabalhador ciente desta proibição no curso das atividades laborais (BRASÍLIA. Tribunal Superior do Trabalho. Sétima Turma. Processo AIRR-58700-51.2008.5.02.0472, DJE: 02|10|2014 ).

In casu, inferimos que a análise do judiciário trabalhista brasileiro priorizou o caráter pedagógico para a aplicação da sanção disciplinar pelo empregador. Ou seja, primando pela aplicação de penalidades menos severas, como advertência ou suspensão, antes da ruptura do contrato de trabalho, no intuito de reeducar o obreiro para que não volte a reincidir no comportamento abusivo, preservando-se o vínculo laboral.

A segurança da organização empresarial também deve ser resguardada como aspecto essencial ao adimplemento das obrigaçóes contratuais pelo empregado. Não é admissível que o trabalhador, ainda que em caráter jocoso, exponha a potencial risco, a segurança da empresa, clientes, empregador ou terceiros, por expressóes de conteúdo nas redes sociais.

A jurisprudência espanhola nos brinda com a procedência de uma dispensa disciplinar de uma trabalhadora de um supermercado que postou fotos em Facebook com seu cartão privativo de identificação, da caixa forte utilizada pelo empregador, assim como a localização da mesma, em explícito desrespeito às mínimas diretrizes de segurança (ESPANHA. Sentença do Tribunal Superior de Justiça de Andaluzia, Ceuta e Melilla. Sala do Social. Granada. Sentença 2629 /2011. Processo Recurso de Suplicação 2333 /2011. Publicação 10|11|2011). Não há como obscurecer os reflexos perniciosos do ato da trabalhadora para com os principais deveres inerentes ao contrato laboral, colocando em risco concreto o patrimônio empresarial, a segurança da empresa e a integridade dos próprios funcionários e inclusive de outros sujeitos. 
O uso abusivo dos meios informáticos e das redes sociais pelo empregado poderão conduzir à ruptura do pacto laboral pelo empregador se a conduta do obreiro resultar em prejuízos à realização das atividades trabalhistas e na hipótese em que o empregador estabeleceu regras claras, precisas e determinadas sobre o uso dos meios informáticos no curso das atividades laborais. Tornando-se claro para o trabalhador que o uso abusivo dos meios informáticos constitui ilícito grave, nos moldes das diretrizes disciplinares fixadas previamente pelo empregador.

Neste sentido, a Sexta Turma do Tribunal Superior do Trabalho reformou decisão do Tribunal Regional do Trabalho da $4^{\mathrm{a}}$ Região (RS), determinando a não concessão das férias e do décimo terceiro salário proporcionais a um trabalhador dispensado por falta grave, reafirmando os dispositivos da Súmula 171 e da Lei 4.090| 62, os quais restringem o pagamento à dispensa náo motivada. No contexto, o trabalhador, agente administrativo da Companhia Riograndense de Saneamento - Corsan, teve o seu contrato de trabalho extinto pela aplicação de sanção disciplinar como decorrência de falta grave do trabalhador, motivada pelo acesso de 867 sites de conteúdo suspeito e não direcionados às atividades laborais por ele pactuadas, em apenas dois dias.

O fato foi constatado pelo empregador, através do monitoramento dos meios informáticos pela área tecnológica da empresa, tendo o empregador alegado, ademais, que a fiscalização no âmbito tecnológico também constatou que o trabalhador havia instalado um programa para burlar o Proxy da rede e a contaminação e propagação de um vírus o qual atingira o servidor da empresa.

No panorama supra, resta claro que o empregado burlou, conscientemente, vários aspectos fundamentais à preservaçáo do contrato de trabalho, resultando na conseqüente sanção disciplinar e ruptura do pacto laboral (BRASÍLIA. Tribunal Superior do Trabalho. Sexta Turma. Processo ARR-184-34.2011.5.04.0001).

Assim, vale salientar que os empregados devem adotar posturas adequadas no ambiente eletrônico e, em hipótese alguma, utilizar-se dos meios informáticos | eletrônicos para a realização de contatos íntimos, prática de ofensas, atos ilícitos ou antiéticos.

Por outro lado, cabe ressaltar que a doutrina jurisprudencial do Supremo Tribunal Espanhol (ESPANHA. Sentença do Tribunal Supremo. Madrid. Sala do Social. $1^{\text {a }}$ Turma. Sentença 8876/2011. Recurso de Cassação 4053/2010. Publicação 06/10/2011), consagra que as políticas empresariais de controle ao uso do meios informáticos pelo empregado, deverão explicitar, ademais, sobre o monitoramento e o controle de tais ferramentas laborais para que os registros sejam lícitos e as provas obtidas por tal poder fiscalizatório do empregador sejam considerados como legítimas.

De qualquer modo, torna-se aconselhável para assegurar a segurança jurídica de contratantes e contratados, adequar apartados na regulamentação da empresa que tratem 
sobre a postura dos trabalhadores no uso das redes sociais, abstendo-se de expressóes de pensamentos que possam trazer conseqüências danosas à moral, à honra e à integridade física e | ou psíquica dos sujeitos envolvidos com às atividades laborais.

Desta forma, a estipulação de normas comportamentais sobre postura e conduta no uso das tecnologias no ambiente de trabalho, poderá ser efetuada pela empresa, diretamente, como medida decorrente do poder de organização, inclusive através de manuais e cartilhas informativas, perfilando as boas práticas no ambiente laboral; ou poderá encontrar previsão na norma coletiva negociada.

\subsection{Uso das Redes Sociais em Meio Privado, com Vinculação Expressa ao Exer- cício das Atividades Laborais}

Nesta hipótese há uma nítida expressão nas relaçóes laborais de comportamentos que, a priori, constituem atos da vida privada do trabalhador. Sendo assim, a própria rede social consolidará o instrumento probatório para o ilícito obreiro, viabilizando a ruptura disciplinar pelo empregador.

Neste âmbito a jurisprudência é farta, ao tratar-se de severos inadimplementos das obrigaçóes contratuais pelo trabalhador, em nítida afronta aos princípios basilares que regem as relações não patrimoniais no contrato de trabalho. Não há como olvidarmos que existe um código legal de condutas, impostas ao trabalhador e que, quando afrontadas, admitem a ruptura disciplinar pelo empregador, com as respectivas sançóes econômicas aplicáveis.

Neste panorama, a relação laboral encontra-se viciada pela quebra da boa fé contratual por parte do trabalhador contratado. A rede social tão somente apresenta-se como reflexo de uma falta grave, legalmente tipificada, que já havia sido praticada pelo empregado, a partir do momento em que se configura o animus para lesionar o sujeito contratante.

Ilustrativamente, pode-se apontar como hipóteses que conduzem a ruptura disciplinar do pacto laboral, situaçóes nas quais o trabalhador encontra-se afastado das atividades por incapacidade temporária para o trabalho em virtude de depressáo, mas publica em redes sociais fotos em festas e com a ingestão de bebidas alcoólicas. Resta clara a intençáo de lesionar a parte contratante, mediante o uso de artifícios medonhos para ludibriar a boa fé patronal (ESPANHA. Sentença do Tribunal Superior de Justiça de Madrid. Sala do Social. 5a Turma. Sentença 00032/2012. Recurso de Suplicação 3803/ 2011. Publicação $23|01| 2012)$.

Ora, o contrato laboral envolve sinalagmas, cabendo ao trabalhador prestar os serviços, ao mesmo tempo que corresponderá ao contratante o pagamento da contraprestação. Se não há realização das atividades pelo empregado, de forma livre e voluntária, 
sem qualquer motivo legalmente justificado, igualmente, não haverá o pagamento da contraprestação. A normatização social veda o locupletamento. Se o empregado se utiliza de estratagemas para burlar a ordem lógica do pacto laboral, claro estará a afronta aos preceitos de probidade, pedra angular para dito contrato.

Em idêntico sentido, uma sentença do Supremo Tribunal Espanhol declarou como procedente, a dispensa disciplinar de uma trabalhadora que após iniciar os trâmites para o afastamento temporário de suas atividades, por motivo de enfermidade, viajou até Madrid, postando fotos em facebook de um passeio em um parque, que havia realizado com suas amigas (ESPANHA. Tribunal Superior de Justiça Astúrias. Sala Social de Oviedo. Sentença 01333|2013. Processo Recurso de Suplicação 0000241|2013. Publicação 14 |06| 2013).

Sob similar ângulo, os perfis nas redes sociais também poderão servir como mecanismos probatórios valiosos para a processualística trabalhista. Ou seja, para comprovar a infração do trabalhador, conforme expostos nos casos anteriormente citados ou no tocante a outros aspectos essenciais ao legítimo cumprimento do contrato de trabalho.

Neste último sentido, em Santa Catarina, uma empresa apresentou o perfil profissional do trabalhador no Twitter e no LinKedIn como prova para tentar desconstituir o vínculo empregatício com um representante comercial, contestando a presença do vínculo com a hipótese de tratar-se de representante comercial autônomo, ao apresentar-se como representante de outras empresas. Tentativa frustrada, posto que o judiciário trabalhista, pós análise do conjunto probatório, reconheceu a existência do vínculo (BRASÍLIA. Tribunal Superior do Trabalho. Sexta Turma. Processo AIRR-1390-19.2012.5.12.0036. DEJT 04|12|2014).

O Tribunal Superior do Trabalho brasileiro também se posicionou no sentido de conceder danos morais aos antigos empregadores, dois médicos veterinários, de uma exfuncionária de uma clínica veterinária que utilizou-se de sua página, em uma rede social, para proferir expressóes agressivas contra os ex-contratantes, admitindo, inclusive, que havia procedido com comportamentos inadequados contra os animais dos patróes. Para instruir o citado processo, os ex-empregadores da trabalhadora buscaram o Tabelionato de Notas e Registro Civil para a expedição da ata notarial de constatação de conteúdo de endereço da Internet, com a íntegra transcrição das conversas expostas pela antiga funcionária (BRASÍLIA. Tribunal Superior do Trabalho. Quinta Turma. Processo RR-62574.2011.5.09.0001. Publicação 20|11| 2012).

Consideramos coerente a decisão da Corte trabalhista. Por certo, apesar dos comentários terem sido postados após a ruptura do pacto laboral, resta nítido, ao senso comum, que a conduta ilegítima houvera sido praticada em pleno desenvolvimento das atividades pertinentes ao vínculo empregatício, tendo a empregada confessado, inclusive, a prática 
de atos criminosos contra animais, o que, efetivamente coloca em risco concreto a imagem dos serviços ofertados pelo estabelecimento.

Ademais, os perfis nas redes sociais passam a ser utilizados, no âmbito processual, como meio de provas, tanto se o empregado utilizar expressóes que comprometam à imagem da empresa ou ofendam à honra do empregador ou ainda como meio comprobatório da desídia do trabalhador em pleno horário e local de trabalho.

\subsection{Comentários e Expressões Ideológicas nas Redes Sociais}

Esta, indubitavelmente, constitui a hipótese mais emblemática para a configuração da ruptura do contrato de trabalho pela aplicação da sanção disciplinar oriunda do poder patronal. Situação que compóe o eixo central da presente investigação, por apresentar interrogantes e obscuridades quando em cotejo com as fundamentais garantias à liberdade de expressão, estatuídas pelos documentos internacionais e cartas constitucionais que abordam à temática.

Sob esta perspectiva, enfatiza-se que grande parte da doutrina especializada e os Tribunais Sociais albergam a tese de que os essenciais pilares do pacto laboral, baseados na confiança e na boa fé entre os sujeitos contratantes, apresentam-se desconstituídos quando a parte contratada realiza comentários, reflexóes e publicaçóes em redes sociais ou outros sítios da web que representem graves violaçóes aos deveres inerentes ao contrato laboral.

Assim, torna-se comum a ruptura do pacto laboral por sanção disciplinar imposta pelo empregador como resultado de expressóes públicas efetuadas pelo trabalhador em redes sociais e que coloquem em risco à segurança e à ordem econômica da empresa e à integridade física e psíquica dos indivíduos, relacionados ao vínculo laboral. As puniçôes mais severas ao trabalhador baseiam-se na argumentação de configurarem agressóes explícitas aos direitos fundamentais e às garantias contratuais, preconizadas em todo e qualquer contrato de trabalho.

Por outro lado, torna-se inconcebível que o livre pensamento do trabalhador, em seus reflexos expressivos, mediante postagens nas redes sociais possam ser tolhidos em face ao arbítrio do empregador, travestido de poder disciplinar. Há que se respeitar, tutelar e assegurar as expressóes livres de consciência e ideologias, direito de todos os indivíduos, resplandecente nos Estados Democráticos de Direito.

Sob este aspecto, cabe apartar duas condutas diferenciadas pertinentes ao uso das redes sociais pelo trabalhador: o exercício legítimo do direito fundamental à liberdade de expressão, das transgressóes abusivas violadoras da boa fé, confiança e lealdade no cumprimento das obrigaçóes contratuais. Eis, pois, os esclarecimentos que apresentamos no tópico seguinte. 


\section{0 Direito Fundamental à Liberdade de Expressão do Trabalhador no Uso das Redes Sociais. Paradigmas e Incongruências}

Há um tênue liame entre o legítimo exercício do direito fundamental à liberdade de pensamento e suas expressóes nas redes sociais com relação aos comportamentos abusivos e violadores do pacto laboral. Diferenciar os paradigmas entre o correto e as contravençóes pode tornar-se tarefa das mais árduas ao analisarmos os efeitos nos casos concretos.

Em território nacional, uma auxiliar administrativa da Sáo Paulo Transportes S.A. (SPTrans), empresa que administra o transporte público, foi dispensada por justa causa pela postagem, no facebook, de severas críticas à Prefeitura Municipal de São Paulo. O Judiciário trabalhista compreendeu a dispensa como imotivada, posto ter sido a crítica dirigida ao governo municipal e não à empresa contratante (BRASÍLIA. Tribunal Superior do Trabalho. 8a Turma. Processo AIRR-2678-80.2012.5.02.0003. DEJT 18|09|2014).

Nessa hipótese fulgurou uma separação entre o ente contratante e o governo municipal para asseverar como legítima as reflexóes contra este último. O grande questionamento centra-se no fato de que se, porventura, na situação em exame, a trabalhadora se posicionasse de forma contestadora sobre o serviço ofertado pela empresa, talvez a decisão do judiciário houvesse sido outra. Hipótese que nos leva a indagar: ao posicionamento e reflexóes da trabalhadora, nesta última hipótese, agora aventada, caberia o tratamento como liberdade de pensamento ou ilícito punível?

Por outro lado, cabe ressaltar que se a trabalhadora piamente acredita, no mundo de suas ideias, que os serviços prestados pelo sujeito contratante não são zelosos para com o cidadão, por algum motivo. $\mathrm{O}$ fato é que, mesmo ciente disso, a trabalhadora não poderia expressar-se de tal forma nas redes sociais, sob pena de ter o seu contrato extinto por falta grave? Ao respondermos afirmativamente o questionamento proposto, estaremos anuindo pela existência de uma limitaçáo grandiosa à liberdade de expressão do trabalhador em função da existência de um pacto laboral.

Situação de alta complexidade, uma vez que envolve à esfera privada do trabalhador, posto que a falta grave extrapola os limites do ambiente laboral para colocar em constante vigilância a vida do trabalhador, mesmo quando este se encontre fora do alcance direto do controle do poder patronal.

Com efeito, cabe diferenciarmos dois comportamentos relacionados ao uso das redes pelo empregado: os ilícitos que poderão ser punidos, ainda quando praticados fora do local de trabalho e os atos legítimos do trabalhador e que não possuem conexão direta com as atividades desenvolvidas e que, portanto, são estranhos às suas obrigaçóes laborais.

Diante do comportamento do contratado, o grande temor, para o contratante, trata-se do impacto lesivo que as postagens realizadas pelo trabalhador, poderá ocasionar à imagem da empresa, acarretando reflexos negativos no ambiente de trabalho ou 
consequências nefastas à reputação do produto e | ou serviços prestados. Por certo, "La imagen de la empresa se lacera cuando, en lugar de ser un cliente, es el mismo empleado quien la menosprecia” (NOTA, 2012, p.294).

Neste patamar, cabe ressaltar as situaçôes em que a vida privada e a intimidade do trabalhador acabam mesclando-se com o exercício de suas atividades laborais, mediante a propagação de conteúdo, via redes sociais.

O certo é que quanto mais nos aprofundamos na análise, maiores são os percalços labirínticos que encontramos.

Ilustrativamente, podemos citar o caso de um técnico de qualidade do Consórcio Santo Antônio Civil, responsável pela construção da Hidrelétrica de Santo Antônio, em Rondônia, teve o seu contrato de trabalho extinto por falta grave, após serem divulgadas imagens íntimas do seu namoro com uma colega de trabalho, gravadas com o celular desta última. O vídeo tornou-se um viral entre os colegas da obra. Semanas após o ocorrido o técnico foi demitido por incontinência de conduta, acusado pelo escândalo difundido entre os demais integrantes da obra. O empregado negou veementemente que houvera participado na publicação das cenas entre os companheiros de trabalho.

A sentença de primeira instância desconstituiu a justa causa, observando a inviolabilidade da intimidade e da vida privada no tocante à gravação das cenas, não existindo provas de que a divulgação do vídeo partira do trabalhador acusado pela prática do ilícito trabalhista. In casu, o contratante foi condenado ao pagamento das verbas rescisórias e a indenização por dano moral. Desfecho confirmado pelo TRT da 14a Região (RO/AC), e pelo TST, ao negar o agravo de instrumento impetrado pela parte sucumbente (BRASÍLIA. Tribunal Superior do Trabalho. 7a Turma. Processo AIRR-2086-80.2010.5.14.0000. DEJT 28|09|2012).

Resta óbvio que apesar da repercussão negativa no terreno laboral, o contexto apresenta-se como preceito crucial para o exercício da liberdade em atos da vida privada do trabalhador. De fato, gravar imagens íntimas em seus relacionamentos afetivos e postá-las em redes sociais não nos parece campo prolífero para a ingerência patronal na esfera de liberdade do trabalhador. Recordando que outras responsabilidades, cíveis e | ou criminais poderão ser fixadas, dependendo de como as gravaçóes foram efetuadas.

Por outro lado, expressóes singelas nas redes sociais poderão ser tão significativas, no sentido de exprimir anseios e perspectivas, conforme o contexto no qual se apresentam. Nesse patamar, cita-se o fato de que o simples ato de "curtir" uma postagem no Facebook, por exemplo, poderá simbolizar a concordância com uma infinidade de opinióes, ideologias, expressóes. De esta forma, o simples ato de clicar um botão para uma determinada postagem nas redes sociais pode tornar-se algo tấo concreto quanto os prolongados discursos que, amiúde, encontramos nas redes. 
O grande questionamento que podemos apresentar, sob esta perspectiva, é se a manifestação real do pensamento do trabalhador, ao concordar com alguma postagem negativa para o âmbito subjetivo do empregador, constitui ato ilícito justificável da dispensa por infração obreira.

Podemos ilustrar as veredas de nossos pensamentos com um caso concreto, recentemente discutido em nossos tribunais. A Segunda Turma do Tribunal Superior do Trabalho, por unanimidade, negou provimento ao agravo interposto por uma enfermeira da Unidade de Tratamento Intensivo (UTI) do Prontolinda Ltda., em Olinda (PE), que foi dispensada por justa causa após efetuar postagens de fotos suas e da equipe de trabalho, tiradas durante o expediente laboral. $\mathrm{Na}$ ação, a enfermeira pedia a descaracterizaçáo da justa causa e o pagamento de dano moral (BRASÍLIA. Tribunal Superior do Trabalho. Segunda Turma. Processo AIRR - 5078-36.2010.5.06.0000. DEJT 03|05|2012).

O caso supra nos conduz a tecer algumas consideraçóes, suscitando-se elementos conflitantes. Pois bem, a foto foi postada por um trabalhador em específico, tendo sido o único demitido com base no ilícito decorrente do fato em comento. Acontece que, as fotos apresentam um grupo de trabalhadores da saúde. E os demais trabalhadores que anuíram com a exposição de suas respectivas imagens na rede social, seja através da anuência com a publicação, mediante os comentários postados na interface virtual ou pressionando o botão, de maneira favorável, ao conteúdo exposto na rede social?

Com efeito, assemelha-se à criação de dois sistemas diferenciados para aplicação da sanção disciplinar: punir àquele que postou a imagem e perdoar os que não postaram à imagem, mas posicionaram-se em sentido favorável ao contexto. Resultando em favorecimento do direito à liberdade de expressão de alguns trabalhadores e restrição à liberdade de expressão de outros. O que nos parece antagônico e pouco confiável, na perspectiva da segurança jurídica.

É fato que se alguém posta reflexóes relacionadas com a apologia ao crime ou xenófobas e um outro sujeito "curte" tais postagens, livremente estará aderindo àquelas concepçóes. Pois bem, trata-se de uma afirmação concreta de expressão dos pensamentos. Sendo assim, em solo norte-americano, uma sentença prolatada pelo Quarto Tribunal de Apelaçóes de Virgínia considerou que pressionar o botão de curtir para um comentário, foto ou página de facebook, encontra-se amparado pela Primeira Emenda da Constituição dos Estados Unidos que tutela a liberdade de expressão, e, por conseguinte, passando ao status de garantia constitucional. Os magistrados também consideraram que ao apertar o botão "curtir" na rede social, o cidadão está efetuando uma declaração substancial ${ }^{1}$, ato

1 Ver sentença da Corte de Virgínia: “In sum, liking a political candidate’s campaign page communicates the user's approval of the candidate and supports the campaign by associating the user with it. In this 
de liberdade de expressão (ESTADOS UNIDOS DA AMÉRICA. United States Court of Appeals for the Fourth Circuit No. 12-1671 (4:11-cv-00045-RAJ-TEM), 23 de setembro de 2013).

Não há como estabelecermos, de maneira cartesiana, uma fórmula determinante para distinguir o que pode ser considerado como falta de máxima gravidade praticada pelo trabalhador no uso das redes sociais da manifestação legítima do direito fundamental à liberdade de pensamento, consciência e crenças.

A título de curiosidade, cabe reportar uma decisão proferida pelo Tribunal Regional do Trabalho da 10a Região. A Segunda Turma do Tribunal Regional do Trabalho da $10^{\text {a }}$ Região (TRT-10) decidiu que a postagem de mensagem em rede social, no curso do aviso prévio não autoriza a conversão em dispensa por justa causa. No processo em curso, um auxiliar de serviços gerais foi demitido sem justa causa do Instituto Euro Americano de Educação e Tecnologia, em outubro de 2013. Durante o cumprimento do aviso prévio indenizado, o trabalhador divulgou comentários ofensivos sobre a instituição em sua conta de Facebook, para um grupo de amigos. O empregador recorreu ao judiciário trabalhista para converter a ruptura sem falta grave em ruptura derivada de sanção disciplinar do trabalhador.

Para a Corte Recursal não houve intenção em ofender, tratando-se de mero desabafo do trabalhador, insatisfeito pelo rompimento do pacto laboral. Ademais, entendeu o Relator do processo que a reversão em dispensa disciplinar apenas seria possível se o empregador houvera tomado ciência de faltas graves praticadas pelo trabalhador, antes da dispensa; sendo que, a hipotética ação ilícita, situada no caso, ocorreu após a dispensa do obreiro (BRASÍLIA. Tribunal Regional do Trabalho 10a Região. Segunda Turma. Processo no 0001938-33.2013.5.10.014. Publicação 26|11|2014).

Parece-nos que a decisão do Tribunal considerou o caráter intimista e o estado anímico do trabalhador ao postar os comentários críticos no Facebook. Ante as pressóes, decepçóes e injustiças presenciadas e vivenciadas, cotidianamente, quem nunca o fez ou ao menos o idealizou, em seus pensamentos, sob estado de violenta emoção ?

Com efeito, o trabalhador, como qualquer outro cidadão, tem direito à liberdade de expressão, o qual só encontra limitaçóes, em princípio, em outros direitos fundamentais. O jornalista e o radialista, exemplificativamente, podem ferir, no curso de suas atividades,

way, it is the Internet equivalent of displaying a political sign in one's front yard, which the Supreme Court has held is substantive speech" (ESTADOS UNIDOS DA AMÉRICA. United States Court of Appeals for the Fourth Circuit No. 12-1671 (4:11-cv-00045-RAJ-TEM), 23 de setembro de 2013, p.40). Ou seja, os magistrados da Corte consideraram que pressionar o botáo de curtir em uma campanha política representa a aprovação do usuário da rede ao candidato e as propostas da campanha. De forma que, seria o equivalente, para a Internet, a colocar um cartaz de campanha política no jardim de casa, o que a Suprema Corte considera como discurso substancial. 
no âmbito das relaçóes laborais, a honra, a intimidade ou a privacidade de outras pessoas, não dispondo aqueles profissionais de ampla liberdade para divulgar ofensas, agressôes ou atentados à honra individual ou à sensibilidade coletiva dos leitores ou ouvintes (ROMITA, 2007). Por não ser um direito absoluto, não se justifica, em princípio, o uso de expressôes injuriosas e vexatórias em nome da liberdade de expressão (PALOMEQUE LÓPEZ, 2004). Esse direito, assim, deve pautar-se na cláusula de boa-fé, por conta do dever de colaboração que, dinamicamente, é inerente ao contrato de emprego. Do contrário, se o empregado, manifestando publicamente o seu pensamento, causar danos ao nome e ao patrimônio da empresa de forma injusta e abusiva, revela-se perfeitamente possível a sua despedida por justa causa (MEIRELES, 2005).

Por sua vez, o direito de crítica, no Brasil, resta assegurado ao empregado, inclusive pelo fato de que a promoção de um "dissenso construtivo" pode ser uma "ferramenta para melhorar a organização da atividade e a qualidade da produção da empresa” (MELLO, 2014 , p. 27), porém não pode ser exercido de modo a causar injusto dano ao empregador. Em outros termos, o direito de "crítica interna" deve respeitar as regras de urbanidade e cortesia, não sendo razoáveis as manifestaçôes públicas que, gratuitamente, desvalorizam os bens e serviços da empresa ou comprometam a sua gestão (CARVALHO, 2013).

É fundamental, na análise do caso, a aplicação da máxima da proporcionalidade (ROMITA, 2007), e também servem de parâmetros condutas tipificadas penalmente (calúnia, injúria e difamação).

Dessa forma, a não ser quando se trata de informação de relevante interesse público, não pode o empregado, por exemplo, criticar o gosto, a beleza ou a qualidade do produto comercializado pelo empregador, pois se trata de conduta violadora da boa-fé na execução do contrato.

É possível, por outro lado, o empregado denunciar açôes do empregador que sejam absolutamente incompatíveis com as noçóes elementares de interesse coletivo, a exemplo da comercialização de mercadorias que estejam em desconformidade com os seus respectivos rótulos. De igual modo, assegura-se o emprego, por não enquadrar-se como abuso de direito, o dever de falar a verdade em processo judicial como testemunha (MEIRELES, 2005).

Fora da empresa, inclusive, a liberdade de expressão apresenta-se mais ampla, não podendo ser cerceada, a não ser que se vislumbre, por parte da ação praticada pelo trabalhador, violação às regras que vedam o abuso do direito, expondo, indevidamente, o nome da empresa no mercado ${ }^{2}$. Atitudes xenófobas, racistas e antissemitas, certamente,

2 Ilustrativamente, observem-se estes dois casos recentes na mídia brasileira: (I) advogado é ironizado por usar regata e bermuda em aeroporto (http://www.migalhas.com.br/Quentes/17,MI195200,51045Advo- 
não estão protegidas pela liberdade de expressão (MELO, 2014). Em outros termos, o trabalhador pode manifestar-se, inclusive, sobre a empresa e o meio ambiente do trabalho, desde que o faça de forma não abusiva, respeitada e fundamentadamente. Pelos excessos, consequentemente, responderá o empregado (MEIRELES, 2005).

\subsection{Inquirições Contemporâneas: A Prestação de Serviços nas Organizações Ideológicas}

Situação particular abrange as cognominadas "organizaçóes de tendência". Pois bem, além da cláusula geral da boa-fé objetiva, a liberdade de expressão encontra limitação elevada e densa no cerne destas instituiçôes.

Nas "empresas (ou organizaçôes) de tendência” ou "ideológicas", o exercício dos direitos fundamentais, por parte do trabalhador, pode sujeitar-se a limitaçóes quanto à organização empresarial face à exigência de eficaz ou concreta difusão do trabalho ideológico da empresa. Em outros termos, nas empresas de tendência, a convicção política ou a fé religiosa do empregado devem estar em consonância com a orientação ideológica e crença difundidas pela organização empregadora, sem que tal fato implique atentado à liberdade de consciência do trabalhador. São consideradas empresas de tendência, dentre outras, os sindicatos, os partidos políticos e as congregaçóes religiosas.

Observe-se que a finalidade da empresa de tendência deve ser publicamente reconhecida, ou seja, não se trata de um critério subjetivo no sentido de que exclusivamente a empresa defenda uma ideologia; deve, isto sim, configurar um fato externamente constatável. A empresa deve apresentar-se à sociedade, em atos, comportamentos, açóes e atitudes, como defensora de uma ideologia concreta.

A empresa de tendência, diferentemente das demais, pode inserir-se na intimidade e na privacidade do profissional, por possuir uma atividade com princípios religiosos ou ideológicos evidentes. Seu objeto social está diretamente vinculado à sua doutrina, razão pela qual, neste aspecto, poderá questionar, explicitamente, os candidatos nos seus processos seletivos, optando ou não pela contratação do respectivo profissional.

Sendo assim, o princípio da irrelevância das convicçóes políticas e ideológicas do trabalhador, bem como de aspectos de sua vida fora do ambiente de trabalho, inverte-se nas organizaçóes de tendência, de modo a tornar igualmente decisiva, como justa causa de despedimento, a náo conformidade do trabalhador de tendência aos imperativos de ordem ideológica da sua entidade empregadora.

gado+e+ironizado+por+usar+regata+e+bermuda+em+aeroporto); (II) piloto de empresa aérea é despedido por ter xingado nordestinos no facebook (http://brasil.estadao.com.br/noticias/geral,piloto-da-avianca-e-demitido-apos-xingar-nordestinos-no-facebook,1146351). 
Desse modo, pode-se dizer que, no âmbito das empresas de tendência, o trabalhador que esteja diretamente vinculado ao objeto finalístico da empresa poderá padecer alguma mitigação em seu direito à crença ou liberdade ideológica, religiosa e de culto, a não ser que se trate de jornalista com cláusula contratual de consciência.

Sem embargo, em todo caso, torna-se imprescindível a consignação, clara e explícita, das obrigações contratuais assumidas no tocante às finalidades da organização, no bojo das cláusulas contratuais celebradas entre a organização de tendência e os seus trabalhadores. Isto é, ao longo do processo seletivo, certamente, a organização deverá deixar nítida a sua filosofia ou doutrina religiosa, sob pena de ferir o dever de informação decorrente da cláusula geral da boa-fé objetiva (art. 422 do CC).

Se houver descumprimento de deveres contratuais, surge o problema de conciliar as necessidades organizativas da empresa ideológica com a proteção dos direitos fundamentais dos trabalhadores. A resolução do conflito, como não existe regra específica, terá de ser feita casuisticamente, considerando-se a tutela constitucional de que é objeto o direito da organização de tendência de manter inalterada a ideologia que defende e o direito às liberdades fundamentais do trabalhador.

Parece razoável que se a empresa dissemina um conceito ou uma filosofia, ela pode exigir aos funcionários, que exercerão a atividade diretamente ligada ao seu negócio, que sigam seus preceitos. No caso de defesa ambiental, por exemplo, a organização poderá questionar o candidato, no momento da seleção, sobre o que pensa em termos de sustentabilidade ambiental. Se a empresa, por outro lado, busca um profissional para atuar em uma entidade de defesa dos direitos da união homoafetiva, o candidato pode ser recusado, caso tenha postura contra o reconhecimento dos direitos aos homossexuais.

Impóe-se observar que essa regra não vale para todos os funcionários, mas para aqueles que cumprem "tarefas de tendência", também chamadas "tarefas ideológicas". Em outras palavras, as limitações de manifestação de pensamento afetam apenas os trabalhadores cuja prestação de serviços consista especificamente no desenvolvimento da atividade ideológica da empresa. Diferentemente das chamadas "tarefas neutras" (burocráticas, administrativas, de limpeza etc.), as tarefas de tendência são prestaçôes de trabalho de grande conteúdo ideológico, sendo os trabalhadores os que difundem esse ideal (p. ex., professores de uma escola religiosa).

\section{5. À Guisa de Conclusão. A Distopia nas Relações Trabalhistas: Interfaces Tecnológicas vs Liberdade de Expressão vs Poder Disciplinar do Empre- gador}

Com o advento e constantes avanços nas tecnologias de informação e comunicação, e com a expansão e popularização das redes sociais, vivenciamos uma era distópica para 
as relações laborais, com fulcro na relação complexa entre a liberdade de expressão do trabalhador e o poder de controle e sanção, prerrogativas do empregador contratante.

A liberdade propalada no núcleo dos meios informáticos é meramente idílica, pois, no contexto das redes sociais, seremos vistos, analisados, expostos e julgados por, no mínimo, centenas de usuários, ávidos e curiosos em conhecer nossas falácias, êxitos ou vulnerabilidades. O que nos torna, em definitivo, policiados e expostos, em virtude da grande quantidade de expressóes, informaçóes e imagens que, cotidianamente, e muitas vezes de maneira impulsiva, inserimos nas plataformas virtuais.

Certamente, as redes sociais canalizam os pontos mais obscuros da liberdade ilusória. Para os trabalhadores contratados, a liberdade para expressar os pensamentos cede espaço ante às obrigaçóes imanentes ao contrato de trabalho. $\mathrm{O}$ controle patronal, outrora restrito aos muros do ambiente laboral, hodiernamente, multiplica-se em centenas de olhos e vozes no abissal universo cibernético.

Esse cenário emblemático leva-nos a recordar o livro 1984, obra mestra do escritor George Orwell, escrita em 1948. A história acontece em um futuro distópico, no ano de 1984, na Inglaterra, ou Pista de Pouso Número 1, no megabloco cognominado Oceania. A Oceania vivencia um sistema totalitarista, camuflado em democracia, sob o controle do onipresente Big Brother. Há um domínio extremo das pessoas, atos e pensamentos, mediante a asquerosa presença de telas vigilantes e da Polícia do Pensamento, responsável por punir impiedosamente àqueles que ousem praticar crimideia, ou seja, pensar diferente dos paradigmas impostos pelo Partido (ORWELL, 2009).

Ao expressar-se com reflexôes diferentes do sujeito contratante, ao romper com as verdades dominantes impostas pelo empregador, em manifestaçóes antagônicas nas redes sociais, estará o trabalhador praticando uma espécie de "crimideia", ainda que a punição máxima não consista na vaporização pela Polícia do Pensamento, mas, na ruptura do contrato de trabalho. O extermínio não será físico, mas social.

Há uma miscelânea entre os aspectos oriundos da vida privada e o âmbito laboral. Torna-se tarefa Hercúlea apartar o espaço privado do público, posto existir um esfacelamento das noçóes tradicionalmente dispostas sobre espaço e tempo. Isto conduz a uma vigilância permanente do trabalhador com relação às suas postagens, expressóes e imagens veiculadas nas redes sociais.

Não existe liberdade de expressão absoluta e inafastável no seio das redes sociais. Não há. Nem tudo o que guardamos nos fossos ocultos de nossos pensamentos, por mais coerente, justo e lógico que seja, poderemos expressar claramente no divã virtual das redes sociais.

Por certo, não advogamos nenhuma espécie de censura, porém, cabe conscientizar os trabalhadores sobre a necessidade de preservação dos pilares mínimos para a plena 
conservação de um ambiente de trabalho salubre e harmônico. Neste sentido, cabe enfatizar a relevância em se adequar os preceitos essenciais que primam pela liberdade de expressão com os fundamentos de respeito, confiança e lealdade que norteiam as obrigaçóes pactuadas nas relaçóes laborais. Obviamente, não cabe reprimir a livre expressáo de pensamentos a nenhum sujeito, desde que claramente respeitados os contornos mínimos para a convivência laboral.

Em suma, a liberdade imaginária tecida nas amarras da suprema vigilância nos induz aos recônditos dúbios do duplipensar ${ }^{3}$.

\section{Referências}

A) Livros, corpos normativos e revistas especializadas

AMARAL, Francisco. O Direito Civil na pós-modernidade. Em: FIUZA, César; FREIRE DE SÁ, Maria de Fátima; NAVES, Bruno Torquato de Oliveira (Coordenadores). Direito Civil: atualidades. Belo Horizonte: DelRey, 2003.

ARAÚJO, Adriane Reis de. A liberdade de consciência do trabalhador em empresas ideológicas: uma análise da experiência espanhola. Revista LTr. São Paulo: LTr, Ano 77, n. 05, mai. 2013.

ÁVILA, Humberto. Teoria dos princípios: da definição à aplicação dos princípios jurídicos. $11^{\mathrm{a}}$ ed. rev. São Paulo: Malheiros, 2010.

BARROS, Alice Monteiro de. Contratos e regulamentaçóes especiais de trabalho: peculiaridades, aspectos controvertidos e tendências. $4^{\mathrm{a}}$ rev., ampl. e atual. São Paulo: LTr, 2010.

. Proteção à intimidade do empregado. 2a ed. São Paulo: LTr, 2009.

BAUMAN, Zygmunt. Modernidade Líquida. Rio de Janeiro: Zahar, 2014.

BRASIL. Consolidação das Leis Trabalhistas. Decreto-lei n 5452, de 1 de maio de 1943.

. Constituição da República Federativa do Brasil de 1988. Promulgada em 5 de outubro de 1988.

. Código Civil Brasileiro. Lei 10.406, de 10 de janeiro de 2002.

CARVALHO, Catarina de Oliveira. Liberdade de expressáo no trabalho. Em: PINTO, José Augusto Rodrigues; MARTÍNEZ, Luciano; MANNRICH, Nelson. Dicionário brasileiro de direito do trabalho. São Paulo: LTr, 2013.

3 Terminologia esculpida por ORWELL (2009) que se refere à aceitação de duas crenças antagônicas, simultaneamente. 
DUPAS, Gilberto. Ética e poder na sociedade da informaçáo: de como a autonomia das novas tecnologias obriga a rever o mito do progresso. $3^{\text {a }}$ ed. São Paulo: UNESP, 2011.

GÓES, Gisele Santos Fernandes. Princípio da proporcionalidade no processo civil: o poder de criatividade do juiz e o acesso à justiça. São Paulo: Saraiva, 2004.

GRANDE, Cristina; GORDILLO, Carmen. El uso de las redes sociales en la Jurisprudencia Social. Actualidad Jurídica Aranzadi, n855, 2013.

HERVIEU, Benoît. O país dos trinta Berlusconi. Repórteres sem Fronteiras. Brasil: janeiro de 2013.

MARTÍNEZ, María Salvador. El derecho a la libertad de expresión. Em: REYES, Manuel Aragón. Derecho Constitucional. Iustel, 2002. Disponível em: www.documentostics.com. Acesso em: 20 de abril de 2015.

MEIRELES, Edilton. Abuso do direito na relação de emprego. São Paulo: LTr, 2005.

MELLO, Christiane. A liberdade de expressão nas redes sociais: direito de crítica do empregado $\boldsymbol{x}$ imagem e honra do empregador. Revista de Direito do Trabalho, ano 40, n. 157, mai-jun. 2014.

MORAES, Maria Celina Bodin de. Na medida da pessoa humana: estudos de direito civil-constitucional. Rio de Janeiro: Renovar, 2010.

NOTA, Rina G. Díaz. Uso de las redes sociales: ¿Justa causa para despido ? University of Puerto Rico Business Law Journal, v.03, n.02, junho 2012.

ORWELL, George. 1984. Trad: Heloisa Jahn e Alexandre Hubner. São Paulo: Companhia das Letras, 2009.

PALOMEQUE LÓPEZ, Manuel Carlos. Derecho del trabajo y razón crítica. Salamanca: Témpora, Servicios Editoriales, 2004.

PEREIRA, Jane Reis Gonçalves. Interpretação constitucional e direitos fundamentais: uma contribuição ao estudo das restriçóes aos direitos fundamentais na perspectiva da teoria dos princípios. Rio de Janeiro: Renovar, 2006.

ROMITA, Arion Sayão. Direitos fundamentais nas relaçóes de trabalho. $2^{\mathrm{a}}$ rev. e aum. São Paulo: LTr, 2007.

SARMENTO, Daniel. Direitos fundamentais e relaçóes privadas. $2^{\mathrm{a}}$ ed. Rio de Janeiro: Lumen Juris, 2008.

TAVARES, André Ramos. Curso de direito constitucional. $5^{\mathrm{a}}$ ed. rev. e atual. São Paulo: Saraiva, 2007. 


\section{B) Documentos internacionais (Ordem cronológica)}

DECLARAÇÃO Universal de Direitos Humanos (1948). Resolução da Assembleia Geral da ONU, aprovada em 10 de dezembro de 1948.

DECLARAÇÃO Americana dos Direitos e Deveres do Homem (1948).Aprovada na nona Conferência Internacional Americana, Bogotá, 1948.

CONVENÇÃO Europeia para a proteção dos Direitos Humanos e as Liberdades Fundamentais (1950). Roma, 4.XI, 1950.

PACTO Internacional de Direitos Civis e Políticos (1966). Resolução 2200 A (XXI) da Assembleia Geral , aprovada em 16 de dezembro de 1966.

CONVENÇÃO Americana sobre Direitos Humanos (1969). São José, Costa Rica, 7 a 22 de novembro de 1969. 